\title{
CAREER AS A DOMAIN INTRODUCING HIERARCHY IN THE SOCIAL SPACE - A FUNCTIONAL-STRUCTURAL PERSPECTIVE
}

\begin{abstract}
Cybal-Michalska Agnieszka, Career as a Domain Introducing Hierarchy in the Social Space a Functional-Structural Perspective [Kariera jako domena hierarchizująca przestrzeń społeczną - perspektywa funkcjonalno-strukturalna]. Studia Edukacyjne nr 41, 2016, Poznań 2016, pp. 21-35. Adam Mickiewicz University Press. ISSN 1233-6688. DOI: 10.14746/se.2016.41.2

The tradition positioning the study of careers in the structural-functional orientation sees the career as an external system, an objective phenomenon. In this cognitive perspective, a career means a sequence of professional roles fulfilled by the subject, which could mean promotion, stability or degradation. If we adopt an objective criterion to distinguish careers, it would be the positions (professional position or position within the profession) occupied in formal structures. In this sense, a career is not the attribute of an individual, but is the property of the professional role.
\end{abstract}

Key words: career, vertical professional mobility, functional-structural perspective, criterion of promotion, category of the "glass ceiling", career of ethnic minorities

In the structural-functional perspective the separation of the basic structural properties characteristic for the system and used to describe the social reality is accompanied by the belief that the system applies not only to the society or the culture as a whole, but also to the smaller systems within it. ${ }^{1}$ The essence of the functionalist description, focused on the "symbiotic rela-

${ }^{1}$ P. Sztompka, Logika analizy funkcjonalnej w socjologii $i$ antropologii społecznej [The logic of functional analysis in sociology and social anthropology], [in:] Metodologiczne problemy teorii socjologicznych [The methodological problems of sociological theories], Ed. S. Nowak, Warszawa 1971, p. 219. 
tionships between social institutions and their environment"2 lies in the recognition that

the stability, durability of a social system increases as mechanisms are developed that allow the ambitious to advance, and as the minds are increasingly controlled by an ideology requiring individuals to integrate their own life plans into the existing social structure (...), as it is an important element binding the individuals with the society and its institutions. ${ }^{3}$

Education plays a considerable part in maintaining the status quo. As emphasized by Tomasz Gmerek, it is precisely the educational institutions that "play the most significant role in the transmission of socially dominant ideologies and values, and mediate in the assignment of social status to individuals". 4

The tradition positioning the study of careers in the structural-functional orientation sees the career as an external system, an objective phenomenon. As emphasized by S.R. Barley, careers - within the adopted theoretical tradition, reflecting the more or less publicly visible positions and statuses - serve "as turning points in the evaluation of an individual's progress in society". 5 In this cognitive perspective, a career means a sequence of professional roles fulfilled by the subject, which could mean promotion, stability or degradation. In this sense, any subject present on the labor market is "building a career" in the sense of participation in the career domain. ${ }^{6}$ This prompts us to

2 G. Marshall, Stownik socjologii i nauk społecznych [Dictionary of sociology and social sciences], Warszawa 2005, p. 99.

3 Z. Bauman Z., Kariera. Cztery szkice socjologiczne [Career: Four Sociological Sketches], Warszawa 1960, p. 21-24.

${ }^{4}$ T. Gmerek, Kapitalizm - edukacja - nierówność społeczna (Teoria reprodukcji ekonomicznej Samuela Bowlesa i Herberta Gintisa) [Capitalism - education - social inequality (The theory of economic reproduction of Samuel Bowles and Herbert Gintis], [in:] Problemy nierówności spotecznej w teorii i praktyce edukacyjnej [Problems of social inequality in educational theory and practice], Eds. A. Gromkowska-Melosik, T. Gmerek, Kraków 2008, p. 111. It should be noted that the invoked thesis - although it refers directly to the theoretical orientation discussed by the author - is consistent with the logic of structural and functional thinking.

${ }^{5}$ Quoted after: M.B. Arthur, S.N. Khapova, C.P. Wilderom, Career success in a boundaryless career World, Journal of Organizational Behavior, 2005, 26, p. 179.

${ }^{6}$ The issue of professional career domain presented from the functional-structural perspective constitutes a fragment of the multi-contextual approach to the issue of career in a world in which "career makes a career" (both in the theoretical and the research aspect), contained in the monograph entitled Młodziez akademicka a kariera zawodowa [Academic youth and professional career], Kraków 2013. In addition, the issues discussed in the article have already been the subject of considerations and have been published in the Polish language: Kariera jako domena hierarchizująca przestrzeń spoteczna a problem nierówności społecznych [Career as a domain introducing hierarchy in the social space and the problem of social inequalities], 
describe the career in terms of social mobility ${ }^{7}$ (professional mobility), most often meaning the vertical mobility of individuals. The attributes of the subsequent professional roles are a reference point for the characteristics of the subject's career. ${ }^{8}$ In this sense, vertical professional mobility refers to movements in the hierarchy of status or prestige and includes situations where: a) an individual changes their profession and at the same time changes their social position - this movement can be "upward" or "downward", b) an individual does not change their profession, but changes their social position during the practice of that profession - a promotion or a demotion, c) an individual does not change their profession or their position within it, but obtains a higher status in relation to persons at the same position, for example due to the principle of seniority - longer experience at the given work position. Vertical professional mobility includes situations where: a) an individual changes their profession, but does not change their social position, b) an individual doesn't change their profession, and changes their workplace, but retains the same status. ${ }^{9}$ When discussing the movements of individuals Zygmunt Bauman invokes the tacit assumptions:

a) that in the society there are clearly separated and differing positions - otherwise there would be no scale for measuring the road traveled by the individuals; $b$ ) that these positions are arranged in a vertical hierarchy, which means that one is situated higher than the other - otherwise the movement of individuals would be disorderly and non-directional and there would be no criteria for distinguishing "a career" and "a degradation" - both of these concepts would simply become meaningless; c) that despite the clear differences between the positions, their boundaries are porous and it is possible to move from one to the other - otherwise "career" would be an empty concept, without reflection in reality. ${ }^{10}$

Taking into account the changes in the social reality, career has become a social problem only with the advent of capitalism (the overthrow of the feudal relations). ${ }^{11}$ Thus the above findings are not as obvious when ap-

[in:] Edukacja i nierówność. Trajektorie sukcesu i marginalizacji [Education and inequality. Trajectories of success and marginalization.], Eds. A. Gromkowska-Melosik, M. Szymański, Poznań 2014, p. 103-115.

7 Z. Bauman, Kariera, p. 9-10.

${ }^{8}$ E. Rokicka, Pojęcie "kariery". Perspektywa strukturalno-funkcjonalna i interakcjonistyczna [The concept of a "career". The Structural-Functional and the Interactionist perspective], Przegląd Socjologiczny, 1992, XLI, p. 115.

9 Ibidem, p. 121.

${ }^{10}$ Z. Bauman, Kariera, p. 9-10.

${ }^{11}$ Ibidem. 
proached from the historical perspective. Speaking in a metaphorical sense and only indicating the main trends, $\mathrm{Z}$. Bauman put it as follows:

capitalism, on the one hand, retained the distances between the positions of each layer, providing strong incentives for individual careers, and on the other hand broke the glaciers of tradition and filled the rock fissures separating the various levels of the social mountain ranges. Industrialization has created numerous social positions situated high in the hierarchy, which may be the target of a career, and the abolition of formal restrictions opened the access to these positions to lower social classes. $^{12}$

The value of vertical mobility is therefore clearly indicated by sociological approaches, which are based on objective social facts, e.g. upward change of the social position (professional position). A professional career is understood

as a professional biography, climbing through a series of positions in a vertical hierarchy, each of which is situated higher than the previous ones in the social perception, based on the measures of social prestige, wealth, and fame. ${ }^{13}$

In his reflections on "how to build a career" Cyril Northcote Parkinson ponders the "success" of a man, which he treats as a term close to the concept of a "career". He states that if we think of a "man who is successful, and we imagine someone occupying a high position, with a secure future, flawless reputation and good press, and who has acquired all that through his own efforts, ${ }^{14}$ we become aware of the structural-functional understanding of career. Why do we believe that this man is "building a career"? - asks C.N. Parkinson. The answer is not surprising: "for all three of these reasons combined". ${ }^{15} \mathrm{Z}$. Bauman, specified the issue of objective measures of social space, and clearly identified the range of power alongside the measures of social prestige and wealth. The stronger each of the features in this triad, the higher the position of the individual in the social space. ${ }^{16}$

Thus the discussed tradition approaches career as a structural property of the profession, company or organization. Career therefore means a sequence of posts and positions occupied by the typical representative (or one who is considered to be an "ideal" standard model of such a representative)

12 Ibidem, p. 11-12.

${ }^{13}$ W. Duda, D. Kukla, Kariera zawodowa wobec postępujących przemian pracy [Professional career in light of the progressing transformation of work], Częstochowa 2010, p. 40.

${ }_{14}$ C.N. Parkinson, Jak zrobić karierę [In-laws and Outlaws], Warszawa 1972, p. 7.

${ }^{15}$ Ibidem.

16 Z. Bauman, Kariera, p. 11. 
performing the given profession. This approach also stresses the perception of career as "the path of mobility within a single company or organization". ${ }^{17}$ Therefore it is applied both to professions with a hierarchical structure, and to causative agents who move within the occupied professional positions in the performance of their professional roles. If we adopt an objective criterion to distinguish careers, it would be the positions (professional position or position within the profession) occupied in formal structures. The profession is treated as a fundamental characteristic introducing hierarchy in the social space. Other dimensions of the career, or the attributes of position or status (e.g. education, lifestyle, income, participation in culture), are derived from the profession ${ }^{18}$. The foregoing statements are based on a finding invoked by Wioletta Duda and Daniel Kukla:

career is defined as a way to achieve professional excellence in the professional sphere. In order to achieve it, it is necessary to pass many levels in the hierarchy of the organization, which is associated with increasing responsibility, earnings and prestige. ${ }^{19}$

In this sense, a career is not the attribute of an individual, but is the property of the professional role. The subject of a career is not a person as an individual (because, as W. Skidmore put it, "the subject matter of functionalism is not individuals per se"20), but as a holder of a specific professional role (this role is the link connecting the subject with the structure) ${ }^{21}$ practiced in institutional systems. In the institutional approach the features of the subject affect the course of the career, but the career is shaped and decided by the organizational system enabling professional mobility, or more broadly: "the liquidity of social positions".22 A career is therefore defined as an automatic process, consisting in a movement within a set of related posts according to specified promotion criteria. Only in the case of the dimension of power, that is, positions associated with managing teams of workers, we can see distinctions in the formation of career patterns, as they are not an automatic process. Consequently we can distinguish a professional career (orientation on

17 A. Bańka, Proaktywność a tryby samoregulacji [Proactivity and the modes of selfregulation], Poznań - Warszawa 2005, p. 23.

18 E. Rokicka, Pojęcie "kariery”, p. 117 and 122.

19 W. Duda, D. Kukla, Kariera zawodowa, p. 39.

${ }^{20}$ Quoted after: J. Szacki, Historia myśli socjologicznej [History of sociological thought], Warszawa 2003, p. 809.

21 T. Parsons, Szkice z teorii socjologicznej [Sketches of sociological theory], Warszawa 1972, p. 306.

22 See: Z. Bauman, Kariera, p. 15. 
the role) and an organizational career (orientation on the hierarchy of positions). In the case of organizational careers taking into account the criterion of promotion usually means a gradual move away from the criterion of professional role towards the managerial and administrative functions. In the presented perspective a change in the hierarchy of the positions is also an indicator of career. It signifies a change of position in the system of relations: subordination - domination. ${ }^{23} \mathrm{~A}$ career which progresses according to the criterion of promotion, is linear, because it shows progress in the work of a specific nature. The individual relatively early selects the area in which he wants to develop, and has a keen interest in the implementation of the plan of subsequent promotions. ${ }^{24}$ Referring to J. Elster's considerations on the functioning of capitalist companies, the desire of individuals to move up within the professional positions can be explained in a functional way. This is the optimal strategy that allows the individuals who apply it the most effectively to survive on the market. ${ }^{25}$

When organizing the meanings assigned to career within this theoretical orientation, we should emphasize, that career, its properties and their variability are considered as a given, and there are two dimensions to which this concept refers. Z. Bauman indicates the sociological dimension (career as an objective social fact - this category is used to describe mobility within the hierarchy of status during the professional biography of the subjects) and the ideological dimension (the concept of career defines the individual although rooted in social sources - models of success in life, providing the direction for the activity of the individuals). ${ }^{26}$ In fact in terms of the objective methods of identifying careers the dominating criterion is that of promotion, which combines development and implementation of a personal career with constant and quick advancements in terms of status, salary, prestige or power. ${ }^{27}$ Recognizing the length of the promotion path as the essence of the career, we accept the distance between the individual's starting point and the destination point. ${ }^{28}$ The desire for a career associated with the practice of promotions is a driving force and guidepost of the subject's activities (result-

${ }^{23}$ E. Rokicka, Pojęcie ",kariery", p. 118-122.

${ }^{24}$ K.E. Weick, L.R. Berlinger, Career improvisation in self-designing organizations, [in:] Handbook of career theory, Eds. M.B. Arthur, D.T. Hall, B.S. Lawrence, Cambridge 2004, p. 323.

${ }^{25}$ G. Marshall, Stownik socjologii, p. 99.

26 Z. Bauman, Kariera, p. 8-9.

27 A. Bańka, Proaktywność, p. 24.

${ }^{28}$ M. Szymański, Ścieżki kariery studentów socjologii UAM [Career paths of the students of Sociology at the Adam Mickiewicz Univerisity], Warszawa 2010, p. 80. 
ing from the hierarchy of social values). As Z. Bauman put it, the individual seeks

a place of greater splendor, wealth or power than that which they currently occupy. They clearly see the road that is supposed to lead them to that place and hope that they will have enough strength to travel it - they are therefore an ardent defender and supporter of the society where these alluring places, and roads that lead to them, are located. ${ }^{29}$

A good example is the category of "career" understood as a path of professional development, invoked by D.T. Hall, which is associated with the need to occupy the subsequent positions based on promotion and relating to professions of high prestige. D.T. Hall's typology of approaches to career also includes understanding it as its "advancement" which amounts to saying that

it is made by obtaining "something more" - these could be increasingly high positions in the organizational structure, work in an organization perceived as "better", wider decision-making capabilities or greater range of power ${ }^{30}$

and therefore, e.g. an increased range of privileges. "The objective career success" is defined as an external perspective, which determines certain indicators of the subject's career (e.g. profession, professional role, income, social role and social position). In this sense the category of success in a career reflects the "organization" of the understanding of success around status differences. ${ }^{31}$

Attempts at a cognitive approach to career as a dimension introducing hierarchy in the social space are associated with the issue of social inequality. The reference to this category allows us to determine the next problem area for the analysis of issues such as: the impact of race on the career development among ethnic minorities or the barriers in the careers of women (the problem of the "glass ceiling").

The category of the "glass ceiling" (introduced to the discourse in 1986) in social thought is understood symbolically, and aims to capture barriers in a career. It means a multiplicity of barriers faced by women and national

29 Z. Bauman, Kariera, p. 16-17.

30 A. Miś, Kształtowanie karier w organizacji [Shaping careers in an organizations], [in:] Zarzadzanie zasobami ludzkimi. Tworzenie kapitału ludzkiego organizacji [Human resource management. Creating the human capital of the organization], Eds. H. Król, A. Ludwiczyński, Warszawa 2006, p. 477.

${ }^{31}$ Quoted after: M.B. Arthur, S.N. Khapova, C.P. Wilderom, Career success in a boundaryless career World, Journal of Organizational Behavior, 2005, 26, p. 179. 
minorities, who attempt to improve their employment status. The Glass Ceiling Commission, established in 1991, applied this concept to invisible and artificial barriers that prevent qualified individuals from moving to a higher position in the organizational structure and developing their inherent potential. ${ }^{32}$

Although sometimes understood too broadly, the category of the "glass ceiling" is an expression of certain regularities. Cotter wrote that:

artificial barriers impede the advancement of women and national minorities (...) and inequalities arise in the course of life, which means that barriers existing at an early stage of the career become even greater at its later stage. ${ }^{33}$

These views echo the discussions concerning the definition of this concept. It is rarely used to describe and explain the differences in the treatment of women and national minorities in professions at the lower level of the occupational hierarchy. Meanwhile, although the manifestations of unequal treatment due to sex or race can appear in any profession and at all levels of the occupational hierarchy, for considerations in this area we should not use the category of the "glass ceiling", but we should rather refer them to the issues of racial or gender inequality. ${ }^{34}$ In this sense the concept of a "glass ceiling" refers to a situation in which discriminatory tendencies grow along with the individual's position in the professional hierarchy and the differences based on gender or race are the greatest at the higher levels of the organizational structure. This is confirmed by the four criteria for the existence of a "glass ceiling" highlighted by Cotter: (1) the differences arise from the gender or race and cannot be explained by other relevant characteristics of the employee, (2) they are directly proportional to the position in the professional hierarchy, (3) opportunities for promotion, and (4) the level of career development. ${ }^{35}$ The characteristic feature of the discourse on inequality is the tendency to describe and explain this problem by presenting the barriers in careers at the top levels with regard to women and non-white persons. Attention should be paid to "social barriers" referring to a quantitative component (statistical data) and the access of educated women and non-white people to concrete positions. However, the transposition of differences in the

32 C. Akpinar, Career barriers for women executives and the Glass Ceiling Syndrome: The case study comparison between French and Turkish women executives, 2nd International Conference on Leadership, Technology and Innovation Management, Istanbul 2012, p. 4, www.halshs.archi ves-ouvertes.fr/halshs-00738519 [available: 9.02.2015].

33 Ibidem, p. 5.

34 Ibidem.

35 Ibidem. 
structure of occupied positions to the problem of social inequalities requires us to take into account the intra-structural barriers relating to the corporate climate, which is not always conducive to social equality, as well as the governmental barriers, that result from the government's lack of monitoring and implementation of legal solutions adequate to the problem or the lack of accuracy in obtaining data on the scale and complexity of the phenomenon of the "glass ceiling". 36 A separate issue is the perception of barriers in a career, that is, whether individuals see barriers in their carrier, what are these barriers, and whether this is associated with their professional choices. ${ }^{37}$ The phenomenon of male domination and the lack of support structures for women was presented in the report from the research of Tracey Rowe and Anne Crafford ${ }^{38}$ with the use of the metaphorical sense of the fairy tale Cinderella. Barriers to the development of careers of women working in investment banking have revealed, that the development of their career often depends on whether the "shoe fits". The results of the research have also allowed us to confirm, that the parental roles of men and women are treated in a traditional manner. Because of socio-cultural conditions it is the woman who has to play a "motherly" role and the society assesses whether she is a "a good mother". Therefore it makes it difficult for her to maintain a balance between career and motherhood or family life. The society is not as demanding of men - a man who is a father usually has to do less, in order to be considered a "good father". A social structure taking into account the

${ }^{36} \mathrm{Ibidem}$. In this context, it is worth referring to the studies of S.A. Hewlett, who has conducted a nationwide survey in the United States among women occupying important professional positions. In the summary of the results she concluded, that even in organizations whose policy supports women, the general attitude and the pressure associated with the quality of work undermine the position of women and although the professional life of women is developing, the climate of most corporate cultures overwhelms them and limits their thinking about the possibility of realizing their own aspirations. The results of the research of J. Cooper Jackson have brought similar conclusions. She believes that the views and attitudes of the members of the organization (in which women are not seen as leaders), as well as the contextual aspects of the organization (social structures) have an impact on the creation of barriers impeding the development of women's careers. T. Rowe, A. Crafford, A study of barriers to career advancement for professional women in investment banking, Journal of Human Resource Management, 2003, 1(2), p. 21.

37 R.W. Lent, G. Hackett, S.D. Brown, Contextual Supports and Barriers to Career Choice: A Social Cognitive Analysis, Journal of Counseling Psychology, 2000, 1, p. 36-49.

38 T. Rowe, A. Crafford, A study of barriers to career, p. 21-27. Qualitative research with the use of a semi-structured interview was conducted in order to investigate the barriers encountered by professionally active women. The fairy tale Cinderella allowed for the interpretation of the results, because in a society where gender roles are clearly defined, traditional tales accurately reflect the attitudes towards the definition and expectations of the gender as a social construct. 
needs of men means that women have to "play" their professional role according to the rules established by men. The decision on whether and when to start a family, has long-term consequences for the development of women's careers, and the attempt to maintain a balance between work and family life does not guarantee success in either of the two spheres. ${ }^{39}$ It is worth adding that, as noted by Agnieszka Gromkowska-Melosik, for women the "tyranny of choice" concerns many social systems of reference and one can

get the impression that a woman should be like a radio - "tuned" to the frequency appropriate at the given moment, and to be appropriate in the given situation, that she should have an unlimited potential in the field of "tuning", and be this way and that way and some other way, all at the same time. ${ }^{40}$

Investment banking is an industry dominated by men, and the factor of "masculine ties" and the "obsessive character type" can mean that women have limited access to this profession, and even when they enter it, they have few opportunities to make decisions. The sex of the clients of this industry's institution also reflects male dominance, and therefore the clients expect to be served by men. From the results of these studies it can be concluded that a woman who wants to be taken seriously should behave like a man. However, when this style of behavior is utilized by a woman it is seen as a defensive mechanism, and mixed with feminine emotions it means that, as one of the respondents put it, "if you try to compete with your colleagues, you are seen as a bitch" ${ }^{41}$ As a result, many women in leadership positions in the industry play peripheral roles, working in human resources or finance, while the men sit on the management board. The situation of black women is also peculiar, as they are seen not only through the prism of gender, but also the color of their skin, while their skills and competencies are ignored. It should be noted, however, that the creation of barriers to women's career development is also promoted by the lack of support structures, that is, the lack of other women in a male-dominated industry. ${ }^{42} \mathrm{Al}-$ though it is analytically useful, the concept of the "glass ceiling" is also a source of semantic confusion. While there is evidence of the existence of

\footnotetext{
39 Ibidem, p. 23.

${ }^{40}$ A. Gromkowska-Melosik, Socjalizacja, równość społeczna i przemieszczona emancypacja kobiet. Kontrowersje wokót Power Girl [Socialization, social equality and the displaced emancipation of women. The controversy surrounding Power Girl], [in:] Problemy nierówności społecznej, p. 111.

${ }^{41}$ T. Rowe, A. Crafford, A study of barriers to career, p. 22-24.

42 Ibidem, p. 25.
} 
the phenomenon of the "glass ceiling" for women in the labor market, the racial inequalities among men are difficult to explain using this category. Therefore the adopted criteria do not allow for explaining all the barriers in a career, because they clearly associate the "glass ceiling" syndrome with the variable of sex. ${ }^{43}$

F. Dickens and J.B Dickens drew attention to the issue of the career of black managers in an organization and their attempt at a positive integration of their skin color with their professional identity and their involvement in the fight against racism. The model of the development of careers of black managers created by them shows the process of development of their careers independently of the existing models of experience development in the career of white managers. In light of the fact that in the early stages of their careers black workers struggle with the realization of the phenomenon of social inclusion and the crystallization of their professional identity, the authors identified four career stages: entry, adaptation, planned development and success. ${ }^{44}$ The first stage (entry) consists in the shaping of a black individual's relations with the structure of the organization; it is dominated by: a sense of apparent security, ignoring the issue of race, lack of awareness of institutional policy. Among the attitudes and emotions we can distinguish: the sense that one has "managed" to get the coveted job, the lack of focus or marginal focus on goals and the lack of awareness of standards, organizational culture, suppressed anger and ignoring of interpersonal discomfort. The behavior reveals the distance, attempts to fit in and attention to the comfort of the white workers. The second stage (adaptation) is dominated by dissatisfaction, lack of self-esteem and the perception of unequal treatment of black and white workers. This is accompanied by frustration, difficulty in controlling the feelings of anger and rage, and lack of consent to the experienced insults. The attitudes and emotions that emerge later include: dissatisfaction, anger and frustration caused by the lack of mobility, low self-esteem and lack of trust towards white workers. This results in verbal skirmishes with white workers, withdrawal from joint activities and a decrease in work efficiency. In the third stage (planned development) the individual learns to cope with the experienced frustration and anger and strategically chooses the moment to show their dissatisfaction. The individual represents a style which remains in compliance with the standards of the corporation, while retaining a sense of own uniqueness and otherness. At this stage, it is possible to establish satisfactory relations with white employees and pursue con-

${ }^{43}$ C. Akpinar, Career barriers for women, p. 5.

${ }^{44}$ D.A. Thomas, C.P. Alderfer, The influence of race on career dynamics: theory and research on minority career experiences, [in:] Handbook of career theory, p. 139. 
structive cooperation. The awareness that climbing up the career ladder will require more energy than in the case of white workers leads to an increased sense of self-esteem, and setting personal goals promotes activation aimed at eliminating barriers, the development of one's own style, nurturing relationships with others and defining the expectations of the corporation. In the fourth stage (success) the individual, who is aware of the organization's policy and is focused on the results of their work, manifests high self-esteem, improves their professional and interpersonal competencies and develops the style of confrontation with the white workers while maintaining their dignity and mutual respect. The awareness of the peculiarity of racism and being black, as well as the knowledge about the possibility of influencing the corporation and sensitivity to the work environment help in the effective communication and development of one's own style, and are conducive to defining and achieving goals. The model of a black worker's career is associated with the processes of redefinition (the discontinuation of reactive behavior by the subject, clarification and implementation of one's own objectives based on a positive sense of personal identity, as well as showing support to fellow blacks) and internalization (internalization of the acquired knowledge and experience, sense of security, sense of personal identity) and indicates the need for further research on the quality of the individual differences and the impact of the organizational context on the course of the career. The researchers allow for the possibility of repetition of the above stages in the case of promotion or change of organization by the subject. 45 This also applies to the study of the complexity and the determinants of the situation of women on the labor market, where men dominate in the triad of values consisting of prestige, power, and money. Generally speaking, there is a need for studies on social inequalities in the context of differences in the careers of women and men, with the assumption, that such an explanation requires the analysis of both the visible and the hidden barriers preventing women from being promoted to higher positions.

The issue of career can be approached in different contexts and can take into account different criteria for the development of a person's (professional) career. The presented functionalist view on the career environment

assumes, that the established patterns of organizational structures are effective, and the purpose of human resource planning is to maintain the structure in which appropriately qualified people work. ${ }^{46}$

${ }^{45}$ Ibidem, p. $138-141$.

${ }^{46}$ M.B. Arthur, D.T. Hall, B.S. Lawrence, Generating New directions in career theory: The case for a transdisciplinary approach, [in:] Handbook of career theory, p. 19. 
The picture that emerges from this, shows the organization as a dominating entity, which is a lot more subjective than the subject himself, who is at the most seen as a "diagnostician" or a "planner", reacting to the structure of the organization, rather than shaping it. ${ }^{47} \mathrm{New}$ processes of differentiation, multidimensionality and interdependence of the various spheres of social life and the cultural pluralization of the modern world influence the cognitive practice, compelling us to take into account the knowledge about career in the highlighted paradigm, as a dimension introducing hierarchy in the social space and orienting our thinking towards analytical instruments enabling the description of the phenomenon of social inequality. The awareness of the fact that the logic of change of society's organizational configuration is not easy to grasp, prevents us from ignoring the "atheoretical nature of many sociological findings". ${ }^{8}$ As emphasized by Ernst Gellner, although many theoretical orientations are subject to devaluation, the use of the presented logic of the adopted paradigmatic code in new, completely different conditions is more difficult than in the past, but highly desirable nonetheless. ${ }^{49}$ Contemporary careers in the Western European civilization succumb to the neo-liberal logic of a globalizing society. The functional-structural interpretation is a paradigm explaining social differentiation, emphasizing the essence of causal relationships between institutions and activities, and their contribution to the integration of the social structure.

\section{BIBLIOGRAPHY}

Akpinar C., Career barriers for women executives and the Glass Ceiling Syndrome: The case study comparison between French and Turkish women executives, 2nd International Conference on Leadership, Technology and Innovation Management, Istanbul 2012, www.halshs.archives-ouvertes.fr/halshs-00738519 [available: 9.02 2015].

Arthur M.B., Khapova S.N., Wilderom C.P., Career success in a boundaryless career World, Journal of Organizational Behavior, 2005, 26.

Arthur M.B., Hall D.T., Lawrence B.S., Generating New directions in career theory: The case for a transdisciplinary approach, [in:] Handbook of career theory, Eds. M.B. Arthur, D.T. Hall, B.S. Lawrence, Cambridge University Press, Cambridge 2004.

${ }^{47}$ N.E. Bell, B.M. Staw, People as sculptors versus sculpture: The roles of personality and personal control in organizations, [in:] Handbook of career theory, p. 233.

48 A. Manterys, J. Mucha, Nowe perspektywy teorii socjologicznej. Punkt widzenia $2009 \mathrm{r}$. [New perspectives of sociological theory. Point of view of 2009], [in:] Nowe perspektywy teorii socjologicznej. Wybór tekstów [New perspectives of sociological theory. Selection of texts], Eds. A. Manterys, J. Mucha, M. Kaczmarczyk, Warszawa 2009, VII.

${ }^{49}$ M. Flis, Funkcjonalizm [Functionalism], in: Encyklopedia socjologii [Encyclopedia of Sociology], vol. I, Warszawa 1998, p. 234-235. 
Bańka A., Proaktywność a tryby samoregulacji [Proactivity and the modes of self-regulation], Studio Print-B, Poznań - Warszawa 2005.

Bauman Z., Kariera. Cztery szkice socjologiczne [Career: Four Sociological Sketches], Iskry, Warszawa 1960.

Bell N.E., Staw B.M., People as sculptors versus sculpture: The roles of personality and personal control in organizations, [in:] Handbook of career theory, Eds. M.B. Arthur, D.T. Hall, B.S. Lawrence, Cambridge University Press, Cambridge 2004.

Cybal-Michalska A. (ed.), Tożsamość w kontekście edukacyjnym i społeczno-kulturowym. Między partykularyzmem a uniwersalizmem [Identity in the educational and sociocultural context. Between particularism and universalism], Wydawnictwo Naukowe UAM, Poznań 2011.

Cybal-Michalska A., Młodzież akademicka a kariera zawodowa [Academic youth and professional career], Oficyna Wydawnicza Impuls, Kraków 2013.

Cybal-Michalska A., Kariera jako domena hierarchizująca przestrzeń społeczna a problem nierówności społecznych [Career as a domain introducing hierarchy in the social space and the problem of social inequalities], [in:] Edukacja i nierówność. Trajektorie sukcesu $i$ marginalizacji [Education and inequality. The trajectories of success and marginalization], Eds. A. Gromkowska-Melosik, M. Szymański, Wydawnictwo Naukowe UAM, Poznań 2014.

Cybal-Michalska A., Kopeć D., Segiet W. (eds.) Studia z pedagogiki i nauk pogranicza [Studies of pedagogy and boundary sciences], Wydawnictwo Naukowe UAM, Poznań 2011.

Cybal-Michalska A., Wierzba P., (eds.) Dyskursy kultury popularnej w społeczeństwie wspótczesnym [Discourses of popular culture in the contenmporary society], Oficyna Wydawnicza Impuls, Kraków 2012.

Duda W., Kukla D., Kariera zawodowa wobec postęujacych przemian pracy [Professional career in light of the progressing transformation of work], Wydawnictwo im. S. Podobińskiego Akademii im. Jana Długosza, Częstochowa 2010.

Flis M., Funkcjonalizm [Functionalism], in: Encyklopedia socjologii [Encyclopedia of Sociology], vol. I, Oficyna Naukowa, Warszawa 1998.

Gmerek T., Kapitalizm - edukacja - nierówność społeczna (Teoria reprodukcji ekonomicznej Samuela Bowlesa i Herberta Gintisa) [Capitalism - education - social inequality (The theory of economic reproduction of Samuel Bowles and Herbert Gintis], [in:] Problemy nierówności społecznej w teorii i praktyce edukacyjnej [Problems of social inequality in educational theory and practice], Eds. A. Gromkowska-Melosik, T. Gmerek, Oficyna Wydawnicza Impuls, Kraków 2008.

Gromkowska-Melosik A., Socjalizacja, równość społeczna i przemieszczona emancypacja kobiet. Kontrowersje wokót Power Girl [Socialization, social equality and the displaced emancipation of women. The controversy surrounding Power Girl], [in:] Problemy nierówności społecznej w teorii i praktyce edukacyjnej [Problems of social inequality in educational theory and practice], Eds. A. Gromkowska-Melosik, T. Gmerek, Oficyna Wydawnicza Impuls, Kraków 2008.

Gromkowska-Melosik A., Edukacja i (nie)równość społeczna kobiet. Studium dynamiki dostępu [Education and the social (in)equality of women. Study of the dynamics of access], Oficyna Wydawnicza Impuls, Kraków 2011.

Lent R.W., Hackett G., Brown S.D., Contextual Supports and Barriers to Career Choice: A Social Cognitive Analysis, Journal of Counseling Psychology, 2000, 1.

Manterys A., Mucha J., Nowe perspektywy teorii socjologicznej. Punkt widzenia 2009 r. [New perspectives of sociological theory. Point of view of 2009], [in:] Nowe perspektywy teorii 
socjologicznej. Wybór tekstów [New perspectives of sociological theory. Selection of texts], Eds. A. Manterys, J. Mucha, M. Kaczmarczyk, Zakład Wydawniczy Nomos, Warszawa 2009.

Marshall G., Stownik socjologii i nauk społecznych [Dictionary of sociology and social sciences], Wydawnictwo Naukowe PWN, Warszawa 2005.

Melosik Z., Uniwersytet $i$ społeczeństwo. Dyskursy wolności, wiedzy $i$ władzy [The university and society. Discourses of freedom, knowledge and power], Oficyna Wydawnicza Impuls, Kraków 2009.

Melosik Z., Stoneczne (pozakulturowe) wakacje - tożsamość typu "all inclusive" [Sunny (noncultural) vacations - "all inclusive" identity], [in:] Tożsamość w kontekście edukacyjnym i społeczno-kulturowym. Między partykularyzmem a uniwersalizmem [Identity in the educational and socio-cultural context. Between particularism and universalism], Ed. A. Cybal-Michalska, Wydawnictwo Naukowe UAM, Poznań 2011.

Melosik Z., Kultura popularna i tożsamość młodzieży. W niewoli władzy i wolności [Popular culture and the identity of youth. Held captive by power and freedom], Oficyna Wydawnicza Impuls, Kraków 2013.

Miś A., Kształtowanie karier w organizacji [Shaping careers in an organizations], [in:] Zarzadzanie zasobami ludzkimi. Tworzenie kapitatu ludzkiego organizacji [Human resource management. Creating the human capital of the organization], Eds. H. Król, A. Ludwiczyński, Wydawnictwo Naukowe PWN, Warszawa 2006.

Parkinson, Jak zrobić karierę [In-laws and Outlaws], Książka i Wiedza, Warszawa 1972.

Parsons T., Szkice z teorii socjologicznej [Sketches of sociological theory], PWN, Warszawa 1972.

Rokicka E., Pojęcie „kariery”. Perspektywa strukturalno-funkcjonalna i interakcjonistyczna [The concept of a "career". The Structural-Functional and the Interactionist perspective], Przegląd Socjologiczny, 1992, XLI.

Rowe T., Crafford A., A study of barriers to career advancement for professional women in investment banking, Journal of Human Resource Management, 2003, 1(2).

Szacki J., Historia myśli socjologicznej [History of sociological thought], Wydawnictwo Naukowe PWN, Warszawa 2003.

Sztompka P., Logika analizy funkcjonalnej w socjologii $i$ antropologii spotecznej [The logic of functional analysis in sociology and social anthropology], [in:] Metodologiczne problemy teorii socjologicznych [The methodological problems of sociological theories], Ed. S. Nowak, PWN, Warszawa 1971.

Szymański M., Ścieżki kariery studentów socjologii UAM [Career paths of the students of Sociology at the Adam Mickiewicz Univerisity], Wydawnictwo Promotor, Warszawa 2010.

Thomas D.A., Alderfer C.P., The influence of race on career dynamics: theory and research on minority career experiences, [in:] Handbook of career theory, Eds. M.B. Arthur, D.T. Hall, B.S. Lawrence, Cambridge University Press, Cambridge 2004.

Weick K.E., Berlinger L.R., Career improvisation in self-designing organizations, [in:] Handbook of career theory, Eds. M.B. Arthur, D.T. Hall, B.S. Lawrence, Cambridge University Press, Cambridge 2004. 
